\title{
PENGARUH ATMOSPHERE STORE, DESAIN PRODUK, DAN CITRA MEREK TERHADAP KEPUTUSAN PEMBELIAN (Studi Kasus di Rown Division Surakarta)
}

\author{
Laurensius Panji Ragatirta ${ }^{1}$, Erna Tiningrum ${ }^{2}$ \\ Sekolah Tinggi Ilmu Ekonomi Adi Unggul Bhirawa Surakarta \\ E-mail : panjiraga46@gmail.com, ernatiningrum64@gmail.com
}

\begin{abstract}
ABSTRAK
Tujuan penelitian ini adalah Untuk mengetahui Pengaruh Atmosphere Store, Desain Produk, dan Citra Merek terhadap Keputusan Pembelian di Rown Division Surakarta. Lokasi penelitian yang digunakan adalah Rown Division Surakarta kabupaten Surakarta. Dengan jumlah sampel sebanyak 100 responden. Pengambilan sampel dilakukan dengan sample random sampling. Data dikumpulkan dengan cara membuat kuesioner mengenai Keputusan Pembelian, Atmosphere Store, Desain Produk dan Citra Merek. Data hasil penelitian dianalisis dengan teknik uji t, uji F, dan regresi linier berganda. Hasil analisis menunjukkan bahwa: Atmosphere Store berpengaruh positif dan tidak signifikan terhadap Keputusan Pembelian. Desain Produk berpengaruh positif dan signifikan terhadap Keputusan Pembelian. Citra Merek berpengaruh positif dan signifikan terhadap Keputusan Pembelian. Suasana Store, Desain Produk, dan Citra Merek secara bersama-sama berpengaruh signifikan terhadap Keputusan Pembelian. Uji determinasai $\left(\mathrm{R}^{2}\right)$ diperoleh hasil nilai Adjusted $R$ Square sebesar 0.527. Hal ini berarti bahwa variabel Atmosphere Store, Desain Produk, dan Citra Merek pengaruhnya sebesar 52.7\% sedangkan sisanya 47,3\% dipengaruhi oleh variabel lain yang tidak termasuk dalam penelitian ini.
\end{abstract}

Kata Kunci: Atmosphere Store, Desain Produk, dan Citra Merek, Keputusan Pembelian

\section{PENDAHULUAN}

Persaingan di era globalisasi semakin bertumbuh pesat di dunia bisnis. Setiap perusahaan berkompetisi guna menarik pelanggan dan mempertahankan eksistensinya di pasar. Seperti banyaknya pelaku usaha yang mendirikan Distribution Store ( Distro ) di kota kota Indonesia. Distro atau Distribution Store adalah toko yang menjual berbagai jenis pakaian dan juga aksesoris dimana brand yang ada dan tersedia disana adalah brand local ataupun dalam negeri baik yang dititipkan maupun juga yang di produksi sendiri, Rown division adalah salah satu perusahaan distro terbesar yang berdiri di surakarta pada tahun 2007. Dan telah memproduksi bermacam macam produk seperti $t$-shirt, kemeja, celana jeans, sepatu, jacket, topi, dompet, kacamata, tas dll. meskipun terlihat jelas distro berpusat pada penjualan produk, namun dalam prosesnya dan aktivitas jual beli tentu tak dapat terlepas dari berbagai macam hal yang menentukan keputusan konsumen untuk melakukan pembelian di sebuah distro.

Menurut Suharno (2010:96) "keputusan pembelian adalah tahap dimana pembeli telah menentukan pilihannya dan melakukan pembelian produk, serta mengkonsumsinya". Oleh karena itu keputusan pembelian merupakan suatu bagian pokok dalam perilaku konsumen yang mengarah kepada pembelian produk atau jasa. Dalam membuat sebuah keputusan pembelian konsumen tidak terlepas dari faktor yang mempengaruhi dan memotivasi konsumen untuk melakukan pembelian. Beberapa faktor yang mempengaruhi sebuah Distro untuk menarik konsumen dalam melakukan pembelian dapat di lakukan dengan memberikan Atmosphere Store, Desain Produk, dan Citra Merek bagi konsumennya. Atmosphere Store menjadi salah satu variabel yang dapat mempengaruhi keputusan pembelian.

Masing-masing distro memiliki daya tarik, gaya dan suasana yang berbeda-beda baik dari segi kebersihan, tata letak, poster, tulisan, coretan, pelayanan, fasilitas dan back song yang diputar. Itu berarti atmosfer sendiri tercipta melalui suatu gambaran yang tervisual atau fisik yang disuguhkan oleh distro tersebut. tinggal bagaimana distro mampu menciptakan suasana yang tidak membosankan , berbeda dengan yang lain namun tetap nyaman.. atmosfer positif yang tercipta akan mendorong rasa puas dalam diri si pembeli karena tempat dan suasana yang diberikan melalui gambaran dan bukti fisik tersebut tidak mengecewakan, berkualitas dan sesuai dengan yang diharapkan. Semakin cocok dan pas suasana Distro akan berdampak positif dalam mempengaruhi keputusan untuk melakukan pembelian. 
Desain produk di anggap juga dapat mempengaruhi keputusan pembelian. Dengan mengeluarkan desain yang bagus, menarik dan motif yang bervariasi dapat menumbuhkan sikap dan perilaku konsumen untuk melakukan pembelian. Para pengusaha pun saling bersaing untuk menghasilkan dan memberikan desain produk yang sesuai dengan keinginan konsumen. Agar dapat memenangkan persaingan bisnis, perusahaan harus dapat menciptakan atau mengembangkan sebuah produk dengan desain yang menarik dan unggul.

Selain atmosphere store dan desain produk hal lain yang juga mempunyai peran dalam mempengaruhi konsumen untuk melakukan pembelian di sebuah distro adalah citra dari merek itu sendiri. Konsumen pada umumnya akan langsung percaya kepada merek yang sudah terkenal atau dikenal banyak orang karena itu berarti merek tersebut mempunyai citra yang baik di masyarakat. Citra Merek merupakan salah satu hal yang diingat didalam benak konsumen pada saat membeli suatu produk merek tertentu.

Penelitian ini bertujuan untuk mengetahui peran atmosphere store dalam memberi kesan nyaman ketika berbelanja untuk menumbuhkan sikap dan perilaku dalam memutuskan pembelian di sebuah distro. Dengan pengaruh desain yang bermacam macam dari segi gambar ,tulisan dan warna yang melekat dalam citra merek distro Rown Division.

\section{LANDASAN TEORI}

\section{A. Keputusan Pembelian}

Kehidupan manusia tidak lepas dari melakukan jual beli. Sebelum melakukan pembelian, seseorang biasanya akan melakukan keputusan pembelian terlebih dahulu terhadap suatu produk. Keputusan pembelian merupakan kegiatan individu yang secara langsung terlibat dalam pengambilan keputusan untuk melakukan pembelian terhadap produk yang ditawarkan oleh penjual. Pengertian keputusan pembelian, menurut Kotler \& Amstrong (2001) adalah tahap dalam proses pengambilan keputusan pembeli di mana konsumen benar-benar membeli. Pengambilan keputusan merupakan suatu kegiatan individu yang secara langsung terlibat dalam mendapatkan dan mempergunakan barang yang ditawarkan. Definisi lain keputusan pembelian adalah keputusan pembeli tentang merek mana yang dibeli. Konsumen dapat membentuk niat untuk membeli merek yang paling disukai. Keputusan pembelian merupakan suatu proses pengambilan keputusan akan pembelian yang mencakup penentuan apa yang akan dibeli atau tidak melakukan pembelian (Kotler dan Amstrong, 2008).

Menurut Kotler (2005), "Keputusan pembelian adalah Suatu tahap dimana konsumen telah memiliki pilihan dan siap untuk melakukan pembelian atau pertukaran antara uang dan janji untuk membayar dengan hak kepemilikan atau penggunaan suatu barang atau jasa". Kotler (2005) juga menjelaskan yang dimaksud dengan keputusan pembelian adalah suatu proses penyelesaian masalah yang terdiri dari menganalisa atau pengenalan kebutuhan dan keinginan hingga perilaku setelah pembelian.

Pranoto (2008), juga menjelaskan perilaku pengambilan keputusan oleh konsumen untuk melakukan pembelian produk atau jasa diawali dengan adanya kesadaran atas pemenuhan kebutuhan atau keinginan dan menyadari adanya masalah selanjutnya, maka konsumen akan melakukan beberapa tahap yang pada akhirnya sampai pada tahap evaluasi pasca pembelian.

Menurut Paul Peter dan Jerry Olson (1999:162), "Keputusan pembelian adalah proses pengintegrasian yang mengkombinasikan pengetahuan untuk mengevaluasi dua atau lebih perilaku alternatif dan memilih salah satu diantaranya".Menurut Schiffman, Kanuk (2004:547), keputusan pembelian adalah pemilihan dari dua atau lebih alternative pilihan keputusan pembelian, artinya bahwa seseorang dapat membuat keputusan, harus tersedia beberapa alternatif pilihan. 
Dari beberapa pengertian pengambilan keputusan yang telah dipaparkan diatas, maka dapat diambil kesimpulan bahwa keputusan pembelian adalah suatu proses pengambilan keputusan akan pembelian yang akan menentukan dibeli atau tidaknya pembelian tersebut yang diawali dengan kesadaran atas pemenuhan atau keinginan.

\section{B. Atmosphere Store}

Atmosphere store adalah suasana toko yang sangat berpengaruh bagi sebuah toko untuk membuat pelanggan merasa betah dan nyaman memilih- milih jenis produk yang akan dibelinya. Untuk menciptakan suasana yang mendukung dari sebuah toko memerlukan desain yang memadai. Hal itu mencakup desain muka sebuah toko, pintu masuk, sirkulasi pengunjung dari jalan masuk, dan sebagainya. Lalu mengenai tata letak, perlu dipikirkan bagaimana memaksimalkan ruang, seperti mengatur kursi-kursi, meja dan perabotan-perabotan, tanpa mengurangi kenyamanan pelanggan. Selain itu, dalam sebuah distro, perlu dipikirkan mengenai tata cahaya, tata suara, pengaturan suhu udara, dan pelayanan.

Menurut Kotler (2005) "Atmosphere store adalah suasana terencana yang sesuai dengan pasar sasarannya dan yang dapat menarik konsumen untuk membeli". Atmosphere store menyebabkan atau mempengaruhi pembelian. Menurut Christina Widhya Utami (2010) "Atmosphere store merupakan kombinasi dari karakteristik fisik toko seperti arsitektur, tata letak, pencahayaan, pemajangan, warna, temperature,music, aroma secara menyeluruh akan menciptakann citra dalam bentuk konsumen". Benyamin Molan (2004) "Suasana toko merupakan unsur lain dalam perasenjataan produk. Setiap toko mempunyai tata letak fisik yang membuat orang bergerak di dalamnya dengan susah dan mudah". Sutisna (2005) mengatakan Atmosphere store adalah "penataan ruang dalam (instore) dan ruang luar (outstore) yang dapat menciptakan kenyamanan bagi pelanggan".

\section{Desain Produk}

Desain produk adalah totalitas keistemewaan yang mempengaruhi penampilan dan fungsi suatu produk dari segi kebutuhan pelanggan. Dengan semakin ketatnya persaingan, desain akan menjadi salah satu cara yang paling ampuh untuk mendiferensiasikan dan memposisikan produk dan jasa perusahaan. Pemilihan desain produk dilakukan oleh perusahaan dengan terlebih dahulu melakukan analisis berbagai karakteristik pelanggan dan calon konsumen nya. apabila pemilihan desain produk yang dilakukan oleh perusahaan telah dianggap sesuai dengan kebutuhan, keinginan dan selera konsumen yang pada mulanya hanya melihat untuk merespon dan kemungkinan terjadinya keputusan pembelian. Berikut peneliti paparkan pengertian-pengertian desain produk dari beberapa ahli : Kotler dan Amstrong (2012:332) menyatakan desain produk sebagai totalitas fitur yang mempengaruhi tampilan, rasa, dan fungsi produk berdasarkan kebutuhan pelanggan. Aspek desain dalam kegiatan pemasaran merupakan salah satu satu pembentuk daya tarik terhadap suatu produk. Desain dapat membentuk atau memberikan atribut pada suatu produk, sehingga dapat menjadi ciri khas pada merek suatu produk.

Ciri khas dari suatu produk tersebut pada akhirnya akan dapat membedakannya dengan produk-produk sejenis merek lain dari pesaing (Kotler dan Amstrong,2001). Desain produk dapat berupa peningkatan maupun penyederhanaan. Peningkatan pada desain produk berupa penambahan fungsi dan kegunaan dari suatu produk. Sedangkan penyederhanaan desain produk bertujuan agar pemakaian suatu produk menjadi semakin mudah.

Menurut Stanton (1995) desain produk merupakan salah satu aspek pembentuk citra produk. Perusahaan juga makin menyadari pentingnya nilai pemasaran dari desain produk, 
terutama desain penampilannya. Dua faktor yang menyangkut desain produk adalah warna dan kualitas produk. Pemilihan warna yang tepat merupakan keuntungan tersendiri bagi pemasaran suatu produk. Ketepatan manajemen dalam memilih warna apa yang sesuai serta kapan harus mengganti warna produk. Hal ini dapat memberikan keuntungan yang lebih bagi perusahaan apabila perusahaan dapat menggunakan warna secara maksimal. Telah lama diakui bahwa pendayagunaan warna yang tepat dapat meningkatkan penjualan suatu produk. Begitu pula halnya dengan memasyarakatkan secara tepat citra kualitas produk yang sesuai dengan kebutuhan konsumen. Para eksekutif pemasaran harus mampu membuat keputusan keputusan tentang kualitas produknya. Seperti suatu produk harus mampu mencapai tingkat kualitas yang sesuai dengan fungsi penggunaanya.

Bagi pelanggan, produk yang dirancang dengan baik adalah produk yang penampilannya menyenangkan, mudah digunakan dan mudah diperbaiki.Sebuah desain yang unik, lain dari pada yang lain, bisa merupakan satu-satunya ciri pembeda produk.Desain produk yang baik dapat meningkatkan pemasaran produk dalam berbagai hal; misalnya, dapat mempermudah operasi pemasaran suatu produk, meningkatkan nilai kualitas dan keawetan produk, menambah daya penampilan produk.

\section{Citra Merek}

Citra merek adalah sejumlah keyakinan, ide, dan kesan yang dipegang oleh seseorang tentang sebuah objek. Sedangkan citra merek adalah persepsi dan keyakinan yang dipegang oleh konsumen, seperti yang dicerminkan asosiasi yang tertanam dalam ingatan konsumen (Kotler dan Keller,2009).

Menurut Roslina (2010) mendefinisikan bahwa "Citra merek merupakan petunjuk yang akan digunakan oleh konsumen untuk mengevaluasi produk ketika konsumen tidak memiliki pengetahuan yang cukup tentang suatu produk". Terdapat kecenderungan bahwa konsumen akan memilih produk yang telah dikenal baik melalui pengalaman menggunakan produk maupun berdasarkan informasi yang diperoleh melalui berbagai sumber.

Kotler dan Amstrong (2001) mempunyai pendapat bahwa merek merupakan nama, istilah, tanda, simbol, desain, atau kombinasi keseluruhannya, yang ditujukan untuk mengidentifikasikan barang atau jasa yang ditawarkan perusahaan sekaligus sebagai diferensiasi produk. Mereka juga berpendapat bahwa merek itu lebih dari sekedar nama dan lambang. Merek adalah elemen kunci dalam hubungan perusahaan dengan konsumen.Merek merepresentasikan persepsi dan perasaan konsumen atas sebuah produk dan kinerjanya. Merek akan melekat di pikiran konsumen. Nama merek terdiri dari huruf-huruf, kata-kata dan angka-angka yang terbaca.Tanda merek (brand mark) merupakan bagian dari merek yang muncul dalam bentuk simbol, desain atau warna dan huruf khas yang berbeda.Tanda merek hanya dilihat mata tetapi tidak ikut di baca bila konsumen menyebut merek suatu produk.merek mempermudah konsumen mengidentifikasi produk atau jasa. Merek juga bisa membuat pembeli yakin akan memperoleh kualitas barang yang sama jika mereka membeli ulang.

Trade mark adalah brand yang dilindung oleh Undang-undang karena sudah di daftarkan pada pemerintah dan perusahaan mempunyai hak tunggal untuk menggunakannya. Jadi trade mark terdiri atas kata-kata, huruf atau angka-angka yang dapat diucapkan, termasuk juga brand mark (Basu Swasta, 2009). Kotler (2013) mendefinisikan citra merek sebagai keyakinan, ide, dan kesan yang dimiliki oleh seseorang terhadap suatu merek.Kotler (2013) juga menambahkan bahwa citra merek merupakan syarat dari merek yang kuat dan citra adalah persepsi yang relatif konsisten 
dalam jangka panjang (enduring perception). Jadi tidak mudah untuk membentuk citra, sehingga bila terbentuk akan sulit untuk mengubahnya.

Citra yang dibentuk harus jelas dan memiliki keunggulan bila dibandingkan dengan pesaingnya. Saat perbedaan dan keunggulan merek dihadapkan dengan merek lain, munculah posisi merek. Jadi pada dasarnya sama dengan proses persepsi, karena citra merek terbentuk dari persepsi yang telah terbentuk lama. Setelah melalui tahap yang terjadi dalam proses persepsi, kemudian dilanjutkan pada tahap keterlibatan konsumen. Level keterlibatan ini selain mempengaruhi persepsi juga mempengaruhi fungsi memori.

Menurut Aaker dalam Sitinjak (2005) bahwa citra merek adalah seperangkat asosiasi yang ingin diciptakan atau dipelihara oleh pemasar. Asosiasi-asosiasi itu menyatakan apa sesungguhnya merek dan apa yang dijanjikan kepada konsumen. Merek merupakan simbol dan indikator dari kualitas sebuah produk. Merek-merek produk yang sudah lama akan menjadi sebuah citra bahkan simbol status bagi produk tersebut yang mampu meningkatkan citra pemakainya.

\section{TUJUAN PENELITIAN}

Tujuan yang ingin di capai dalam penelitian ini adalah sebagai berikut :

1. Untuk mengetahui signifikansi pengaruh atmosphere store terhadap keputusan pembelian di Rown Divison Surakarta.

2. Untuk mengetahui signifikansi pengaruh desain produk terhadap keputusan pembelian di Rown Divison Surakarta.

3. Untuk mengetahui signifikansi pengaruh citra merek terhadap keputusan pembelian di Rown Divison Surakarta.

\section{KERANGKA PEMIKIRAN}

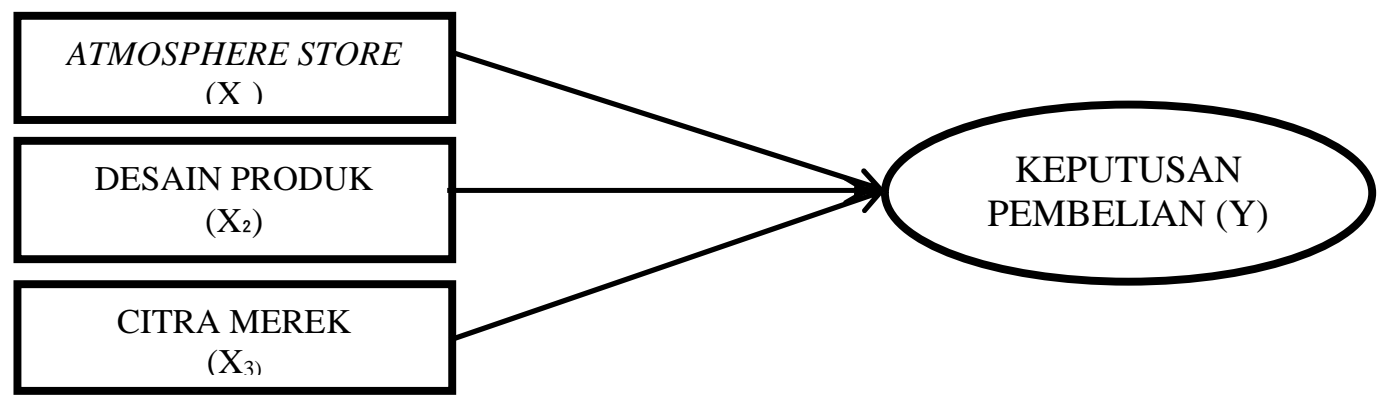

Sumber: Fatkhul Akmal Maulana (2017),Akbar Hanafitrah dan Dr. Widiartanto(2018), Wisnu Kusuma dan Sumarno Dwi Saputra (2015), Achmad Fikri Hanif dan N. Rachma (2017), Afra Wibawa Makna Hidayat (2015).

\section{HIPOTESIS}

H1 : Atmosphere store berpengaruh signifikan terhadap keputusan pembelian di Rown Division Surakarta.

H2 : Desain produk berpengaruh signifikan terhadap keputusan pembelian di Rown Division Surakarta. H3 : Citra merek berpengaruh signifikan terhadap keputusan pembelian di Rown Division Surakarta. 


\section{METODE PENELITIAN}

Lokasi penelitian adalah Rown Division beralamat di Jl. Adi Sucipto No.1 Manahan, Solo. Populasi dalam penelitian ini yaitu pengunjung Distro Rown Divison Surakarta bulan November 2018 kurang lebih 1000 pengunjung. Sampel dalam penelitian ini 100 responden. Jenis data dan sumber data yang akan digunakan adalah data primer yang diperoleh dari kuesioner. Metode pengumpulan data yang digunakan dalam penelitian ini adalah observasi dan kuesioner. Metode Analisis Data dalam penelitian ini yaitu analisis regresi linear berganda, uji T, uji F dan koefisien determinasi.

\section{HASIL PENELITIAN}

\section{A. Analisis Regresi Linier Berganda}

Tabel 1. Hasil Uji Regresi

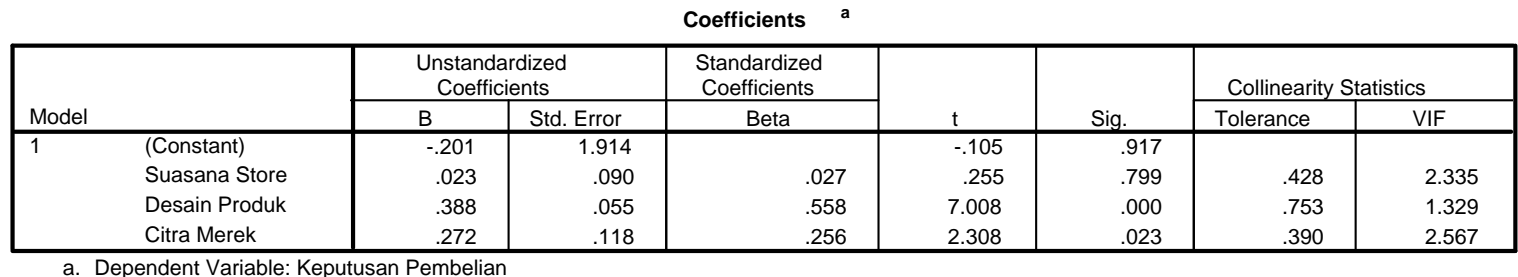

Dengan demikian diperoleh persamaan regresi linier berganda, yaitu:

$$
\text { Y: }-\mathbf{0 , 2 0 1}+\mathbf{0 , 0 2 3 X 1}+\mathbf{0 , 3 8 8 X 2}+\mathbf{0 , 2 7 2 X 3}
$$

Dari persamaan tersebut di atas dapat diinterpretasikan sebagai berikut:

a. Nilai konstanta $(\alpha)=-0,201$, artinya apabila variabel independen ( atmosphere store, desain produk, dan citra merek ) di anggap konstan atau tetap maka keputusan pembelian akan negatif.

b. Nilai $\beta_{1}=0.023$ artinya variabel atmosphere store berpengaruh positif terhadap keputusan pembelian. Hal ini berarti apabila variabel suasana store di tingkatkan, maka keputusan pembelian di Rown Division Surakarta akan meningkat.

c. Nilai $\beta_{2}=0.388$ artinya variabel desain produk berpengaruh positif terhadap keputusan pembelian.

Hal ini berarti apabila variabel desain produk di tingkatkan, maka keputusan pembelian di Rown Division Surakarta akan meningkat.

d. Nilai $\beta_{3}=0,272$ artinya variabel citra merek berpengaruh positif terhadap keputusan pembelian.

Hal ini berarti apabila variabel citra merek di tingkatkan, maka keputusan pembelian di Rown Division Surakarta akan meningkat.

\section{B. Uji T}

Tabel 2. Hasil Uji Statistik t

Coefficients

\begin{tabular}{|c|c|c|c|c|c|c|c|c|}
\hline \multirow{2}{*}{\multicolumn{2}{|c|}{ Model }} & \multicolumn{2}{|c|}{$\begin{array}{l}\text { Unstandardized } \\
\text { Coefficients }\end{array}$} & \multirow{2}{*}{$\begin{array}{c}\begin{array}{c}\text { Standardized } \\
\text { Coefficients }\end{array} \\
\text { Beta } \\
\end{array}$} & \multirow[b]{2}{*}{$\mathrm{t}$} & \multirow[b]{2}{*}{ Sig. } & \multicolumn{2}{|c|}{ Collinearity Statistics } \\
\hline & & $B$ & Std. Error & & & & Tolerance & VIF \\
\hline \multirow[t]{4}{*}{1} & (Constant) & -.201 & 1.914 & & -.105 & .917 & & \\
\hline & Suasana Store & .023 & .090 & .027 & .255 & .799 & .428 & 2.335 \\
\hline & Desain Produk & .388 & .055 & .558 & 7.008 & .000 & .753 & 1.329 \\
\hline & Citra Merek & .272 & .118 & .256 & 2.308 & .023 & .390 & 2.567 \\
\hline
\end{tabular}

a. Dependent Variable: Keputusan Pembelian

Berdasarkan hasil uji statistik t pada tabel di atas dapat diinterpretasikan sebagai berikut: 
1. Atmosphere Store $\left(\mathrm{X}_{1}\right)$ mempunyai nilai signifikansi $0.799>0,05$, sehingga dapat disimpulkan bahwa suasana store berpengaruh tidak signifikan terhadap Keputusan pembelian, dengan demikian hipotesis 1 ditolak.

2. Desain Produk $\left(\mathrm{X}_{2}\right)$ mempunyai nilai signifikansi $0.000<0,05$, sehingga dapat disimpulkan bahwa desain produk berpengaruh signifikan terhadap Keputusan pembelian, dengan demikian hipotesis 2 diterima.

3. Citra Merek (X3) mempunyai nilai signifikansi $0.023<0,05$, sehingga dapat disimpulkan bahwa citra merek berpengaruh signifikan terhadap Keputusan pembelian, dengan demikian hipotesis 3 diterima.

\section{Uji F}

Hasil pengujian dengan menggunakan program SPSS dapat dilihat pada tabel berikut dengan tingkat signifikansi $5 \%(\alpha=0.05)$

Tabel 3. Hasil Uji F

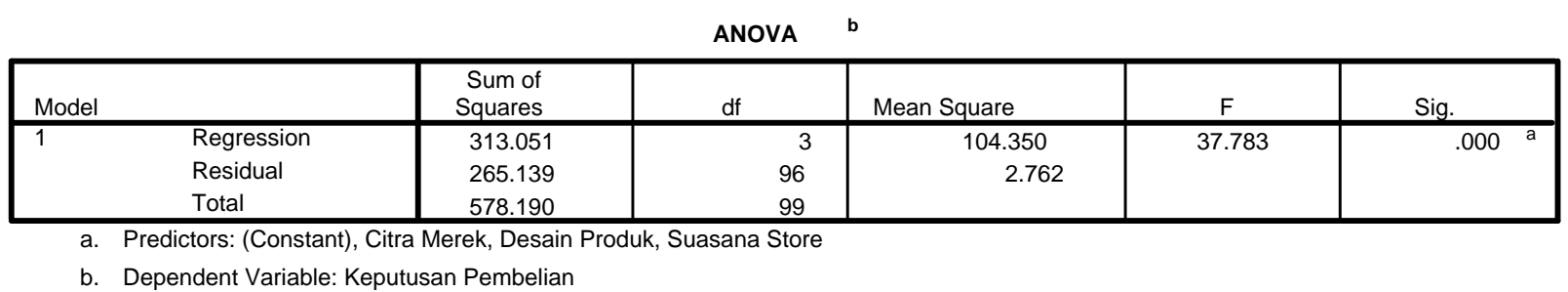

Berdasarkan hasi uji t di peroleh nilai $\mathrm{F}$ sebesar 37.783 dengan tingkat signifikan 0,000 $<0,05$. Sehingga dapat di simpulkan secara bersama sama variabel atmosphere store, desain produk, dan citra merek berpengaruh signifikan terhadap keputusan pembelian di Rown Divison Surakarta.

\section{Koefisien Determinasi $\left(\mathbf{R}^{2}\right)$}

Berdasarkan hasil pengolahan data dengan menggunakan SPPS diperoleh hasil dibawah ini:

\section{Tabel 4. Hasil Uji Koefisien Determinasi}

\begin{tabular}{|c|c|c|c|c|c|}
\hline \multicolumn{6}{|c|}{ Model Summary } \\
\hline Model & $\mathrm{R}$ & R Square & $\begin{array}{l}\text { Adjusted } \\
\text { R Square }\end{array}$ & $\begin{array}{l}\text { Std. Error of } \\
\text { the Estimate }\end{array}$ & $\begin{array}{l}\text { Durbin- } \\
\text { Watson }\end{array}$ \\
\hline 1 & $.736^{a}$ & .541 & .527 & 1.662 & 1.935 \\
\hline
\end{tabular}

Berdasarkan hasil uji koefisien determinasi di atas di dapatkan nilai Adjusted $R$ Square sebesar $0.52,7$ yang berarti keputusan pembelian di jelaskan oleh variabel atmosphere store, desain produk, dan citra merek sebesar 52,7\% sedangkan sisanya ( $47,3 \%$ ) di jelaskan oleh variabel lainnya yang tidak termasuk dalam penelitian ini seperti promosi, harga, kualitas dan lain lain.

\section{IMPLIKASI HASIL PENELITIAN}

Berdasarkan hasil penelitian tersebut diatas dapat diimplikasikan sebagai berikut:

1. Pengaruh desain produk terhadap keputusan pembelian Hasil penelitian menunjukkan bahwa desain produk berpengaruh positif dan signifikan terhadap keputusan pembelian. Hal ini mendukung penelitian yang di lakukan oleh Wisnu Kusuma dan Sumarno Dwi Saputra (2015), Achmad Fikri Hanif dan N. Rachman (2017) yang menunjukkan bahwa desain produk berpengaruh positif dan signifikan terhadap keputusan pembelian. 
Upaya yang dapat di lakukan guna meningkatkan desain produk yaitu

a) memperkuat karakter desain agar berbeda dengan distro distro lain

b) menjaga mutu desain agar desain produk sesuai dengan harapan konsumen

c) melakukan inovasi agar desain produk yang di hasilkan tidak tertinggal trend

d) memahami selera konsumen dari masa ke masa.

Dengan adanya peningkatan desain produk di atas, maka keputusan pembelian di Rown Division Surakarta di harapkan meningkat secara optimal.

2. Pengaruh citra merek terhadap keputusan pembelian Hasil penelitian menunjukkan bahwa citra merek berpengaruh positif dan signifikan terhadap keputusan pembelian. Hal ini mendukung penelitian yang di lakukan oleh Afra Wibawa Makna Hidayat (2015), Achmad Fikri Hanif dan N. Rachman (2017) yang menunjukkan bahwa citra merek berpengaruh positif dan signifikan terhadap keputusan pembelian.

Upaya yang dapat di lakukan guna meningkatkan citra merek yaitu

a) Komitmen terhadap kualitas atribut produk.

b) Membina hubungan citra merek dengan konsumen.

c) Meningkatkan pemahaman terhadap aspek-aspek perilaku konsumen dalam Mengambil keputusan pembelian .

d) Meningkatkan kepercayaan konsumen terhadap produk.

e) Meningkatkan keunggulan bersaing berkelanjutan.

Dengan adanya peningkatan citra merek di atas, maka keputusan pembelian di Rown Division Surakarta di harapkan meningkat secara optimal.

3. Pengaruh atmosphere store terhadap keputusan pembelian Hasil penelitian menunjukkan bahwa atmosphere store berpengaruh positif dan tidak signifikan.

Upaya untuk mempertahankan suasana toko yang baik, yaitu

a) mampu mempertahankan desain internal dan eksternal toko sesuai selera pengunjung.

b) memberikan musik bervariasi, memberikan fasilitas dan pelayanan yang sesuai.

c) Mempertahankan penataan display yang rapi, pengharum ruangan dan kebersihan toko yang selalu terjaga.

Dengan adanya upaya mempertahankan atmosphere store di atas, diharapkan konsumen akan bertahan dan tidak beralih pada pesaing.

\section{KESIMPULAN}

Berdasarkan analisis data mengenai pengaruh Atmosphere Store (X1), Desain Produk (X2), Citra Merek (X3 ) terhadap Keputusan Pembelian (Y), dapat diambil kesimpulan sebagai berikut:

1. Berdasarkan hasil hipotesis variabel Atmosphere Store, Desain Produk, dan Citra Merek berpengaruh positif terhadap Keputusan Pembelian di Rown Division Surakarta.

2. Berdasarkan hasil uji $\mathrm{T}$ variabel Atmosphere Store berpengaruh tidak signifikan terhadap Keputusan Pembelian di Rown Division Surakarta.

3. Berdasarkan hasil uji T variabel Desain Produk dan Citra Merek berpengaruh signifikan terhadap Keputusan Pembelian di Rown Division Surakarta.

4. Berdasarkan hasil uji F variabel Atmosphere Store, Desain Produk, dan Citra Merek secara bersama-sama berpengaruh signifikan terhadap Keputusan Pembelian di Rown Division Surakarta.

5. Berdasarkan hasil perhitungan koefisien determinasi (R2) menunjukkan nilai Adjusted $R$ Square sebesar $52,7 \%$, hal ini berarti diketahui bahwa pengaruh yang diberikan oleh variabel independen terhadap variabel dependen sebesar 52,7 \% sedangkan sisanya 47,3\% dipengaruhi oleh variabel lain yang tidak termasuk dalam penelitian inimisalnya promosi, harga, kualitas produk, dll. 


\section{Saran}

Sesuai dengan kesimpulan diatas, maka peneliti memberikan saran-saran sebagai berikut:

1. Desain Produk berpengaruh berpengaruh positif dan signifikan terhadap Keputusan Pembelian di Rown Division Surakarta, oleh karena itu penulis menyarankan Rown Division Surakarta dapat mengembangkan desain produk yang lebih baik, mengembangkan ide ide kreatif mengenai desain agar selalu mengikuti trend dari masa ke masa, memahami selera konsumen, menjaga mutu desain, dan memperkuat karakteristik desain yang di produksi Rown Division Surakarta.

2. Citra Merek berpengaruh positif dan signifikan terhadap Keputusan Pembelian di Rown Divison Surakarta oleh karena itu penulis menyarankan Rown Division Surakarta memperkuat citra mereknya dengan mempertahankan kualitas produk yang semakin baik, mempertahankan kesan yang baik di mata konsumen, meningkatkan keunggulan bersaing dengan berkomitmen terhadap kualitas seperti atribut, mutu, dan produk produk yang di hasilkan Rown Division Surakarta.

3. Peneliti berikutnya diharapkan dapat menggunakan populasi yang lebih luas dan sampel yang lebih besar sehingga hasilnya akan lebih baik.

4. Peneliti berikutnya diharapkan dapat mengembangkan variabel penelitian yang lain misalnya lokasi, harga, kualitas produk dll.

\section{DAFTAR PUSTAKA}

Arikunto, Suharsimi. 2001. Prosedur Penelitian Suatu Pendekatan Praktek. Jakarta: Bina Aksara.

Arikunto, S., 2007, Prosedur Penelitian Suatu Pendekatan Praktek Edisi Revisi VI hal 134. Jakarta,Rineka Apta.

Augusty Ferdinand,(2006) Metode Penelitian Manajemen : Pedoman Penelitian untuk Skripsi, Tesisdan Disertasi Ilmu Manajemen, Semarang : Badan Penerbit Universitas Diponegoro.

Azwar, Saifuddin. 2007. Reliabilitas dan Validitas. Yogyakarta, PustakaPelajar.

Bambang Pranoto. 2008. Pengaruh Harga dan Kualitas Produk Terhadap Keputusan Konsumen Membeli

Kendaraan Bermotor, Jurnal Ilmiah Faktor Extra Vol.1 No. 2 september 2008.

Bambang Supomo dan Nur Indriantoro, 2002, Metodologi Penelitian Bisnis, Cetakan Kedua. Yogyakara; Penerbit BFEE UGM.

Ballantine, P.W,Jack R and Person A.G. 2010. Atmosphere cues and their effect on the hedonic Retail experience, International journal of retail and Distribution Managemen Vol.38 No.8, pp 641653.

Basu Swastha. 2009. Manajemen Penjualan. Yogyakarta, BPFE.

Basu Swastha. (2000). Pengantar Bisnis Modern, Pengantar Ekonomi Perusahaan Modern, Jakarta : Liberty.

Berman, Barry dan Evans, Joe R. 2004. Retail Management A Strategic Apporoach Ninth Edition. New Jersey. Pearson Education International.

Da Silva, Rui Vintas, dan Alwi, Sharifah. 2006."Cognitive, Affective Attributes and Conatives Behaviounal Responses in Retail Corporate Bandung". Journal of Product and Brand Management Vol 15.

Fandy Tjiptono, Ph.D. 2015. Strategi Pemasaran,Edisi 4. Penerbit Andi Yogyakarta.

Ghozali, Imam. 2005. Aplikasi Analisis Multivariate dengan SPSS. Semarang: Badan Penerbit UNDIP.

John M.Echols dan Hassan Shaldy.2005. Kamus bahasa inggris indonesian. An english - indonesia and dictionary. Jakarta PT.Gramedia. 
Kotler, Philip,(2000). Marketing Management, The Millenium Edition. New Jersey : Prentice Hall International, Inc.

Kotler, Philip. (2001). Manajemen Pemasaran :Analisis, Perencanaan, Implementasi, dan Kontrol. Jakarta : PT. Prehallindo.

Kotler, Philips. 2004. Manajemen Pemasaran Jilid 2. Terjemahan Drs. Benyamin Molan PT. Indeks Kelompok Gramedia.

Kotler, Philip, (2005). Manajemen Pemasaran. Edisi kesebelas. Jilid 2. Edisi Bahasa Indonesia. Jakarta: Penerbit Indeks.

Kotler, Philip dan Amstrong Gar. 2006. Prinsip-prinsip Pemasaran Edisi Kedua Belas. Erlangga Jakarta.

Kotler ,Philip dan Keller, 2007. Manajemen Pemasaran, Jilid 1, Edisi Kedua Belas, Jakarta PT.Indeks.

Kotler, Phillip dan Kevin L, Keller. (2008). Manajemen Pemasaran, Edisi 12 Jilid 1 dan 2, Alih Bahasa : Benjamin Molan, Jakarta, PT.Indeks Gramedia, Jakarta.

Kotler, Philip. 2008. Manajemen Pemasaran. Edisi Milenium. Jakarta: PT. Prenhallindo.

Kotler, Philip dan Gary Armstrong. 2008. Prinsip-prinsip Pemasaran. Edisi Kedua belas. Jakarta: Erlangga.

Kotler, Philip dan Kevin Lane Keller. 2009. Manajemen Pemasaran. Edisi 13. Jakarta: Erlangga.

Kotler, Philip. 2010. Manajemen Pemasaran. Jakarta: PT. Prenhallindo.

Kotler , Philip dan Keller, 2012. Manajemen Pemasaran, Jilid 1, Edisi 13, PT.Indeks, Jakarta Erlangga.

Kuncoro, Mudrajad. 2005. Strategi (Bagaimana Meraih Keunggulan Kompetitif). Jakarta: Penerbit Erlangga.

Levy, M., \& Weitz, B. A. (2001). Retailling Management (4th ed.). Richard D. Irwin Inc.

Levy, M., \&Weitz, B. A. (2012). Retailing Management Information Center. New York: McGraw Hill Higher Education.

Lupioyadi, Rambat. (2001). Manajemen Pemasaran Jasa. Jakarta : Erlangga.

Peter ,J Paul dan Jerry C. Olson. 1999. Consumer Behavior: Perilaku Konsumen dan Strategi Pemasaran. Alih Bahasa Damos Sihombing Jakarta: Erlangga.

Roslina 2010. Citra Merek dan Dimensinya Jurnal Bisnis dan Manajemen. Penerbit Fakultas Ekonomi dan

Bisnis Universitas Lampung.

Schiffiman dan Kanuk. 2004. Perilaku Konsumen. Edisi 7. Jakarta, Prentice Hall.

Schiffman, L.G dan Leslie Lazar Kanuk. 2010. Consumer Behavior Tenth Edition. Pearson Education.

Siswanto, Sutojo 2009, Manajemen Pemasaran, edisi kedua. Jakarta Penerbit: Damar Mulia Pustaka.

Sitinjak, Tony. 2005. "Pengaruh Citra Merek dan Sikap Merek Terhadap Ekuitas Merek". ISSN Vol.12. No.2 Juni. H.166-182

Sugiyono. 2004. Metode Penelitian. Bandung : Alfabeta.

Sugiyono. 2008. Metode Penelitian Kuantitatif Kualitatif dan R\&D. Bandung : Alfabeta.

Sugiyono. 2011. Metode Penelitian Kuantitatif, Kualitatif dan R\&D. Bandung: Alfabeta.

Suharno. 2010. Marketing in Practice. Edisi Pertama. Penerbit Graha Ilmu,Yogyakarta.

Suliyanto (2005), Analisis Data Dalam Aplikasi Pemasaran. Bogor : Ghalia Indonesia.

Sutisna 2005. Manajemen Pemasaran. Edisi Kesebelas. Jakarta. Indeks Utami Christina Widya. 2008.

Manajemen barang dagang dalam bisnis ritel. Malang: Penerbit BayumediaPublishing. 